\title{
Lead Exposure in Trader Communities in Industrial Area of the Battery Recycling Plant: Tangerang, Indonesia
}

\author{
Katharina Oginawati', Rifan Sidhi', Septian Hadi Susetyo ${ }^{1 *}$ \\ 1 Bandung Institut of Technology, Departement of Environmental Engineering, Bandung, Indonesia \\ * Corresponding author's e-mail: aan.ppu@gmail.com
}

\begin{abstract}
The aim of this study was to look at the risk of community around the battery recycling plant in terms of the exposure to lead dust. The number of respondents amounted to 60 people from an industrial area and a residential area. The sample of the industrial area included 30 respondents with a composition of 15 men and 15 women. The same number of respondents was also examined in the residential area as a control area, located $5 \mathrm{~km}$ from the industrial area. Respirable dust was measured using a personal dust sampler, the concentration of lead in dust was measured using GF-AAS, while as a biomarker of exposure, the lead content in urine was measured using GF-AAS. The average values for respirable lead in industrial and residential areas are $0.92 \mu \mathrm{g} / \mathrm{m}^{3}$ and $0.92-1.34 \mu \mathrm{g} / \mathrm{m}^{3}$. The analysis of the lead content in urine for the industrial and residential areas produced an average value of $119 \mathrm{ppb}$ and $123 \mathrm{ppb}$. The average value of $\mathrm{HI}$ for the lead exposure on the industrial and residential areas are in danger (HI> 1) which is $3.6 \pm 1.94$ and $2.18 \pm 1.49$. The OR values for the respondents in the industrial area compared to the residential areas amounting to 1.17 for the category of $\mathrm{HI}$ lead exposure and 1.22 for the category of lead in urine.
\end{abstract}

Keywords: lead exposure, lead in urine, risk assessment heavy metal, battery recycling plant.

\section{INTRODUCTION}

The battery industry is the main consumer of lead from mining $(80 \%)$, while $50 \%$ of the global lead production comes from battery recycling (Gottesfeld 2011; ILZSG). Batteries are used in vehicles, lighting, also in solar panel installations and telecommunication systems for storing energy (Waste 2018; Chen et al. 2009; IC Consultants 2001).

The activity of a battery recycling plant poses a hazard to health. The main danger from battery recycling is lead $(\mathrm{Pb})$ which comes from the destruction of the battery (Lisbona et al. 2011). $\mathrm{Pb}$ is a pollutant that can have acute and chronic effects on health. $\mathrm{Pb}$ is not bound by other elements, so it has the ability to circulate to all body tissues. In adults, $\mathrm{Pb}$ can contribute to heart attacks (cardiotics) and hypertension, whereas brain disorders can occur in children (Jaishankar et al. 2014; Mason et al. 2014).
Lead can have an impact on the central nervous system, the cardiovascular system, the hematopoietic system, slowing psychomotor development, reducing the hearing capacity, and increasing the learning and cognitive capabilities (Reyes 2015; Parzych et al. 2014; Gottesfeld 2011; Sanders et al. 2009; Haefliger et al. 2009; de Freitas et al. 2007; Kosnett et al. 2006). $\mathrm{Pb}$ enters an organism through breathing, subcutaneously (through the skin) and orally (through the digestive tract) (Buser et al. 2016; Matović et at. 2015).

The battery recycling proces activities aim to produce lead in the metal form from the automotive batteries that are no longer in use. Each spent battery contains about $8.2 \mathrm{~kg}$ of lead, consisting of $40 \%$ lead metal and $60 \%$ lead oxide. There are 3 stages of processing the spent batteries, involving scrap pretreatment, smelting and refining (Gratz et al. 2014). 


\section{METHODS}

The stages of preparation are carried out in the form of a location survey to determine the points used as sampling and compilation of the questionnaire. Questionnaires were distributed to determine the respondents to be sampled. The questionnaire given was related to age, weight, length of stay, work time, habits, and the health conditions that might occur due to the exposure to $\mathrm{Pb}$ (Chagnes et al. 2015).

Sampling was carried out at the Industrial area in Jatiuwung District, Tangerang. While the area used as a control sample (background) is a residential area in Curug District, Tangerang, which is located $5 \mathrm{~km}$ from the industrial area. This research is a cross-sectional epidemiological study (Vinceti et al. 2015; Zuberbier et al. 2010). The total number of samples / respondents collected was 60 samples / respondents, with 30 of them in the industrial areas and 30 in the residential areas (background). The respondents in each region were divided into two by sex, namely 15 men and 15 women.

The measurement of the aspirated dust was carried out using the Gilian HFS-513A Hi Flow Personal Sampler tool equipped with a $25 \mathrm{~mm}$ diameter Mixed Cellulose Ester (MCE) filter, $0.8 \mu \mathrm{m}$ density, and SKC aluminum cyclone 22501-01/02 (SKC Catalog, 2003/2004) (Feng et al. 2015; Volchek et al. 2014; Farahat et al. 2010). The measurements were made for 4 hours with a flow rate of $2 \mathrm{~L} / \mathrm{min}$, which was carried out based on the inorganic lead sampling standards. The measurements were performed on the respondent's breathing zone. Dust quantification was conducted gravimetrically, with filter weight measurements made before and after measurement.. Before the measurement of aspirated dust, the measurement of environmental physics parameters, namely temperature, humidity, pressure, and wind speed is also carried out (Monteith et al. 2013; Fink 2015).

The $\mathrm{Pb}$ measurements on aspirated dust are carried out using GF-AAS (Graphite furnaceAtomic Absorption Spectrophotometer), while the measurements of other elements are done using INAA (Instrumental Neutron Atomic Analysis); in turn, the black carbon measurements are carried out using the light reflection method using the EEL smoke stain reflectometer (Taha et al. 2007; Santoso et al. 2013). The measurement of other elements with INAA is needed to identify the source of dust. The measurements of elements with GF-AAS and INAA cannot be done simultaneously, where filters that have been analyzed by GF-AAS cannot be analyzed with INAA, and vice versa. Half of the samples in each region were analyzed using GF-AAS and the other half was analyzed with INAA, each sample was paired based on the closest point (Borges et al. 2015). The urine sampling was carried out by post-shift specimen, wherein the sample was taken at the end of the aspiration dust measurement. The analysis of the $\mathrm{Pb}$ content in urine was carried out using GF-AAS (Aceto et al. 2002; El Ati-Hellal et al. 2007; Kurfürst 2013).

\section{RESULT AND DISCUSSION}

\section{Characteristics of respondents}

The characteristics of the respondents involved in this study were obtained through filling in the questionnaire. This characteristic is needed to determine the equivalence between respondents in the industrial areas and the respondents in the residential areas. In addition, the measurement of respondent characteristics is needed in determining the hazard index. The comparison of characteristics of each region can be seen in Tables 1 and 2. It can be seen that each respondent in the two regions has comparable attributes and deserves to be compared.

\section{Environmental physics parameters}

The environmental physical parameters are wind speed, humidity, temperature, and air pressure. The environmental physical parameters in each region are shown in Table 3 . The probability values $(\alpha=0.05)$ in Table 3 . show that there are no significant differences in terms of the environmental physical parameters between the industrial areas and residential areas.

\section{Hazard index}

The hazard index (HI) of the exposure is calculated using the dose value (ADD) compared to the reference value (RfD). The value of RfD for $\mathrm{Pb}$ is $1,85 \times 10^{-3} \mathrm{mg} / \mathrm{kg}$.day (OMEE, 2010). The dose of aspirated lead exposure is the daily exposure dose (ADD - average daily dose) calculated using Equation 1. In the ADD calculation, 
Table 1. Male respondents equivalence test

\begin{tabular}{|l|c|c|c|c|}
\hline \multirow{2}{*}{\multicolumn{1}{|c|}{ Parameter }} & \multicolumn{2}{c|}{ Average } & \multirow{2}{*}{ Probability value } & \multirow{2}{*}{ Information } \\
\cline { 2 - 4 } & Industrial area & Residential area & & No different \\
\hline Height $(\mathrm{m})$ & $1.62 \pm 0.07$ & $162 \pm 6.70$ & $0.81>0.05$ & No different \\
\hline Weight $(\mathrm{kg})$ & $55.87 \pm 7.14$ & $60.1 \pm 8.58$ & $0.47>0.05$ & No different \\
\hline Length of stay (years) & $14.40 \pm 9.10$ & $15.0 \pm 4.50$ & $0.76>0.05$ & No different \\
\hline Old (years) & $37.06 \pm 8.20$ & $28.3 \pm 7.30$ & $0.51>0.05$ & \\
\hline
\end{tabular}

Table 2. Female respondents equivalence test

\begin{tabular}{|l|c|c|c|c|}
\hline \multirow{2}{*}{ Parameter } & \multicolumn{2}{|c|}{ Average } & \multirow{2}{*}{ Probability value } & \multirow{2}{*}{ Information } \\
\cline { 2 - 4 } & Industrial area & Residential area & & No different \\
\hline Height $(\mathrm{m})$ & $153 \pm 5.06$ & $154 \pm 4.8$ & $0.83>0.05$ & No different \\
\hline Weight $(\mathrm{kg})$ & $63.13 \pm 9.7$ & $57.4 \pm 6.7$ & $0.11>0.05$ & No different \\
\hline Length of stay (years) & $14.80 \pm 10.1$ & $13.2 \pm 3.3$ & $0.41>0.05$ & No different \\
\hline Old (years) & $38.86 \pm 7.4$ & $33.2 \pm 8.6$ & $0.48>0.05$ & \\
\hline
\end{tabular}

Table 3. Environmental physical parameters

\begin{tabular}{|l|c|c|c|}
\hline \multicolumn{1}{|c|}{ Parameter } & Industrial area & Residential area & Probability values \\
\hline Wind velocity $(\mathrm{m} / \mathrm{s})$ & $2.7 \pm 0.73$ & $3.0 \pm 0.795$ & 0.422 \\
\hline Temperature $\left({ }^{\circ} \mathrm{C}\right)$ & $30.4 \pm 1.70$ & $30.7 \pm 1.038$ & 0.252 \\
\hline Humidity $(\%)$ & $61.6 \pm 7.19$ & $58.0 \pm 4.834$ & 0.061 \\
\hline Air pressure $(\mathrm{atm})$ & $1.0 \pm 0.03$ & $1.0 \pm 0.002$ & 0.100 \\
\hline
\end{tabular}

the absorption factor value of $100 \%$ was used, because the lead is assumed to reach the alveoli and enter the circulatory system (Savic et al. 2016).

$$
A D D=\frac{C A \times I R \times E T \times E F}{B W \times A T}
$$

where: $A D D$ is average daily dose ( $\mathrm{mg} / \mathrm{kg}$.day);

$C A$ is The concentration of contaminants in the air $\left(\mathrm{mg} / \mathrm{m}^{3}\right)$;

$I R$ is Average Inhalation ( $\mathrm{m}^{3} /$ hour);

$E T$ is exposure time (hour/day);

$E F$ is frequency of exposure;

$B W$ is weight;

$A T$ is average time $(\mathrm{ED} \times 365$ day/years $)$

(Abd El-Samad et al. 2017).

The average value of the aspirated lead exposure hazard index in each region is shown in Figure 1 . The average daily aspirated lead dose for the industrial areas is $0.00731 \mathrm{mg} / \mathrm{kg} \cdot$ day, and $0.00514 \mathrm{mg} / \mathrm{kg}$. day for the residential areas.

The average HI value is shown in Figure 2. The industrial area is $3.6 \pm 1.94$, while in the residential areas it is $2.5 \pm 0.44$. In order to determine the existence of a significant difference between $\mathrm{HI}$ values in the industrial and residential areas, a comparative test using an unpaired $t$ test is carried out. The results of the comparative statistical test of the unpaired t test show a probability value (p-value) of 0.042 . In the $95 \%$ confidence range, a probability value smaller than 0.05 indicates that $\mathrm{H}_{0}$ is rejected, so it can be concluded that the average HI value of the industrial estate is significantly different from the HI value in the residential area.

The differences in the HI values indicate that the respondents in the industrial areas have a greater risk of exposure to lead compared to the residential areas. The HI values greater than 1, both in the industrial and residential areas, indicate that the respondents in both areas are in dangerous conditions of the $\mathrm{Pb}$ exposure.

\section{Lead concentration}

The lead concentration in the aspirated dust is shown in Figure 3. The average measured aspiration lead concentration in an industrial area was $1.34 \mu \mathrm{g} / \mathrm{m}^{3}$, while in a residential area, it was $0.92 \mu \mathrm{g} / \mathrm{m}^{3}$. The figure shows that all measured lead concentrations are still below the maximum lead exposure standards according to ACGIH (TLV) and OSHA (PEL) at $50 \mu \mathrm{g} / \mathrm{m}^{3}(\mathrm{Li}$ et al. 2015; ACGIH 2004). 


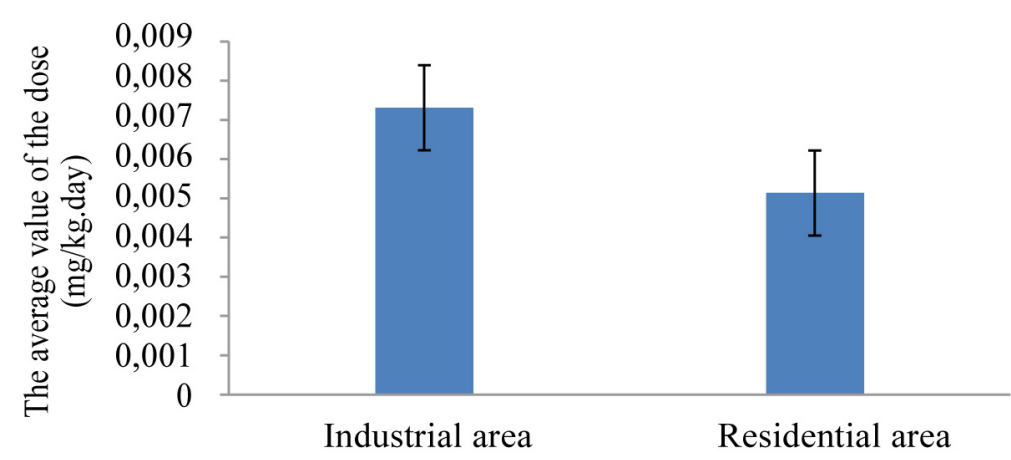

Figure 1. The average value of the aspirated lead exposure

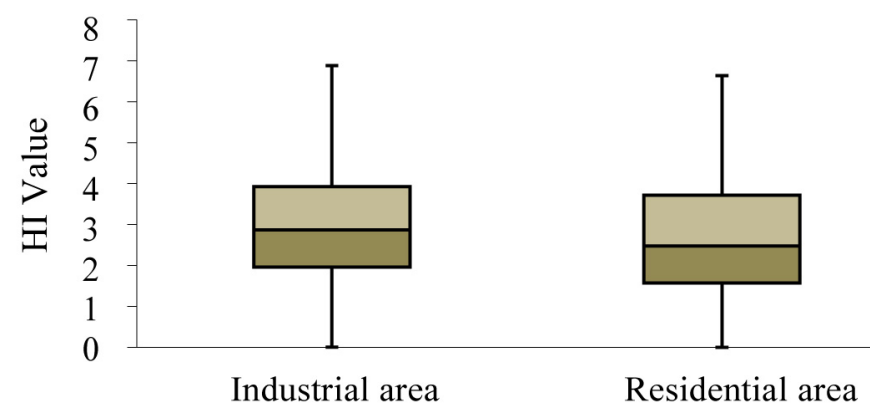

Figure 2. Value of hazard index in each region

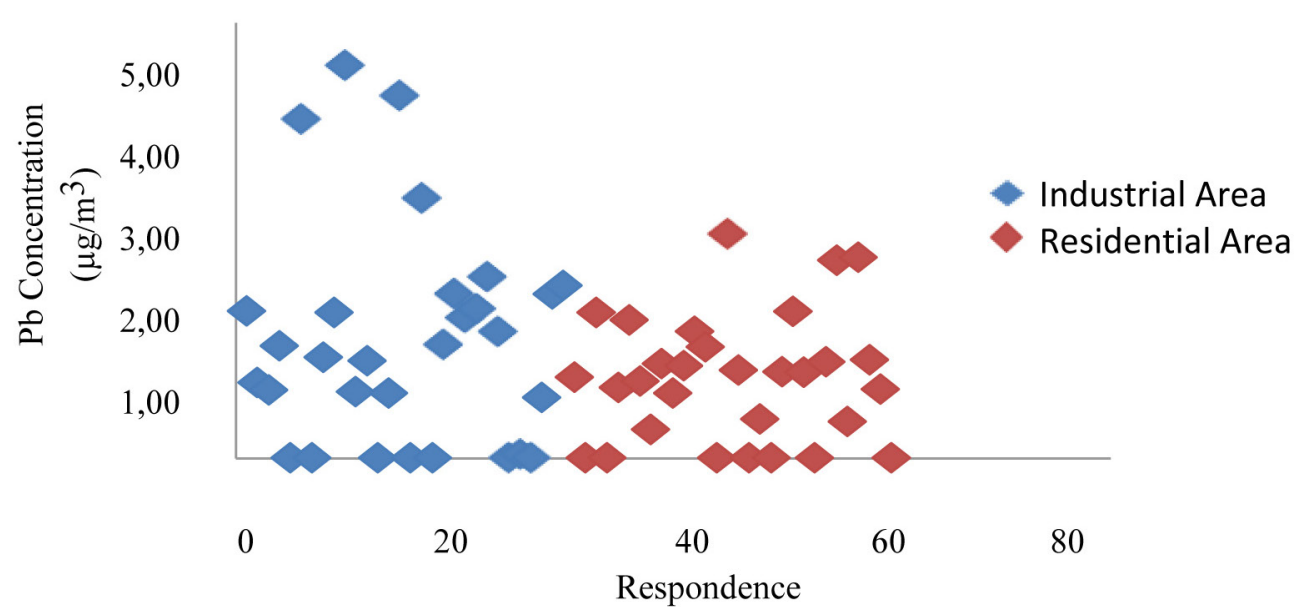

Figure 3. $\mathrm{Pb}$ concentration in the aspirated dust

A comparative statistical analysis using the unpaired test in the two regions produced a probability value of 0.047 in the $95 \%$ confidence range $(\alpha=5 \%)$. The probability value smaller than 0.05 indicates that there is a significant difference between the concentration of lead being absorbed in an industrial area and the concentration of lead aspirated in a residential area (Parks et al. 2014).

The lead concentration in urine is used as a biomarker of exposure. The concentration of lead in urine in each region is shown in Figure 4. The average lead concentration in urine in the industrial area is $119 \mathrm{ppb}$ with a concentration range of 3-541 ppb while in the residential areas it is $123 \mathrm{ppb}$ with a concentration range of 3-628 ppb. There were 12 respondents in the industrial area that had the lead concentrations in urine exceeding the safety standards according to NJDOH (New Jersey Department of Health, 2010), which is $80 \mathrm{ppb}$. In turn, in the residential areas there were 9 respondents who exceeded the average lead concentration in safe urine (Matta et al. 2016; NJDOH 2010).

The comparative statistical analysis to compare the urine lead concentrations in the two 


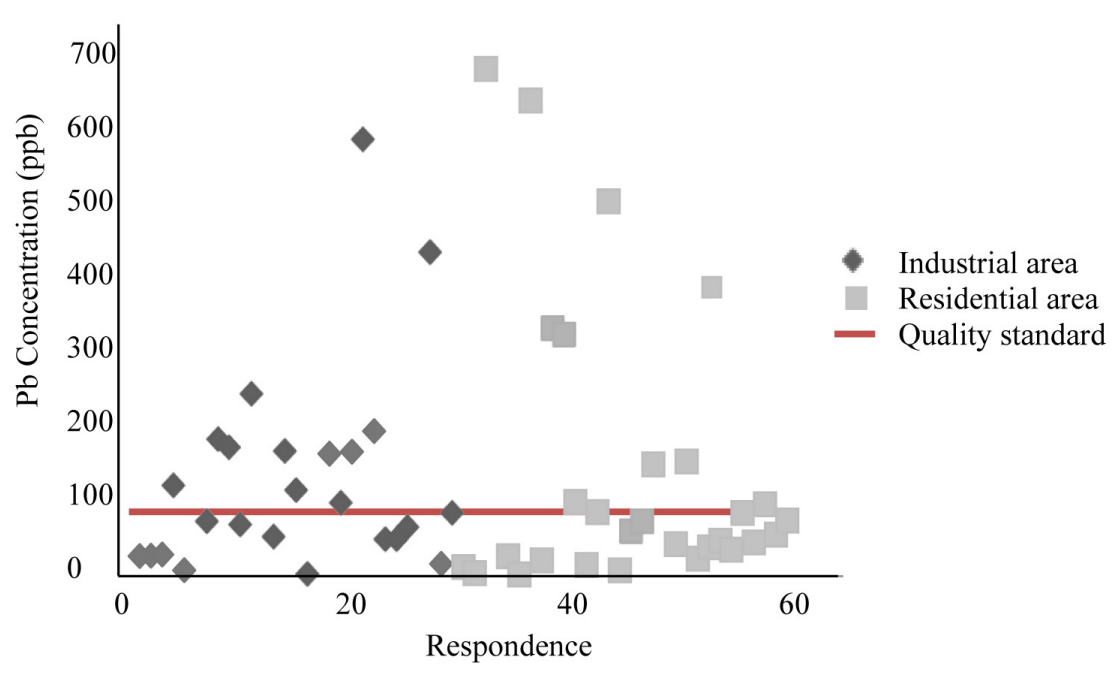

Figure 4. $\mathrm{Pb}$ concentration in urine

regions resulted in a probability value of 0,000 in the $95 \%$ confidence range. The probability values over 0.05 indicate that there is no significant difference in the concentration of urine lead between the respondents in the industrial areas and those in the residential areas. The absence of this difference indicates that the residential areas, which are dominated by non-industrial activities, cannot be separated from the effects of lead exposure.

The relationship between the lead concentration in urine and the distance of lead pollutant sources is shown in Figure 5. It can be seen that as far as the respondents are from the industrial areas are concerned, the lead concentration in the urine of respondents tends to decrease. However, this relationship is not statistically significant, as it can be caused by the differences in the metabolic rate of respondents, and it can also mean that lead in the urine of the respondent does not only come from the lead emissions caused by the industrial area.

\section{Evaluasi Dosis-Respon}

The relationship between the aspirated lead and the lead concentration in urine is shown in Figure 6. The relationship between urine $\mathrm{Pb}$ concentration and $\mathrm{Pb}$ aspired in the industrial area

Figure 6 show a value of $\mathrm{R}^{2}$ that is much smaller than 1 , this shows that only a small portion of urine lead concentration is affected by the amount of the aspirated lead concentration. A correlative statistical analysis using the Pearson correlation test produced the probability values of 0.189 and 0.259 . In turn, the Pearson correlation values (r) produced were 0.272 and 0.225 . The probability values greater than 0.05 indicate that the relationship between the lead concentration in urine with the aspirated lead concentration is not meaningful, as it occurs both in the industrial and residential areas. In addition to the small number of respondents, the difference in a person's

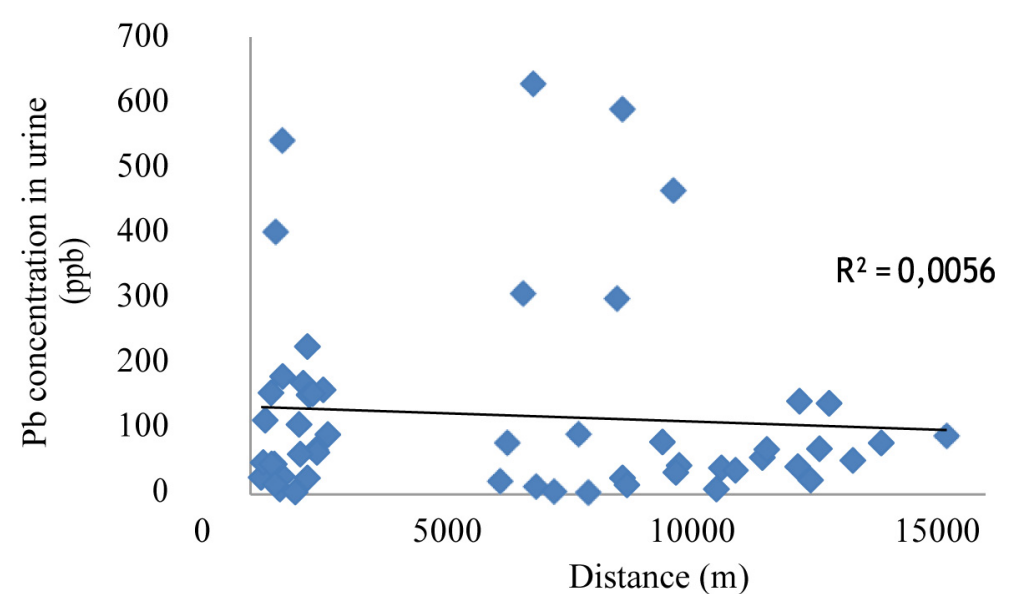

Figure 5. The relationship of lead in urine with distance from companies. 

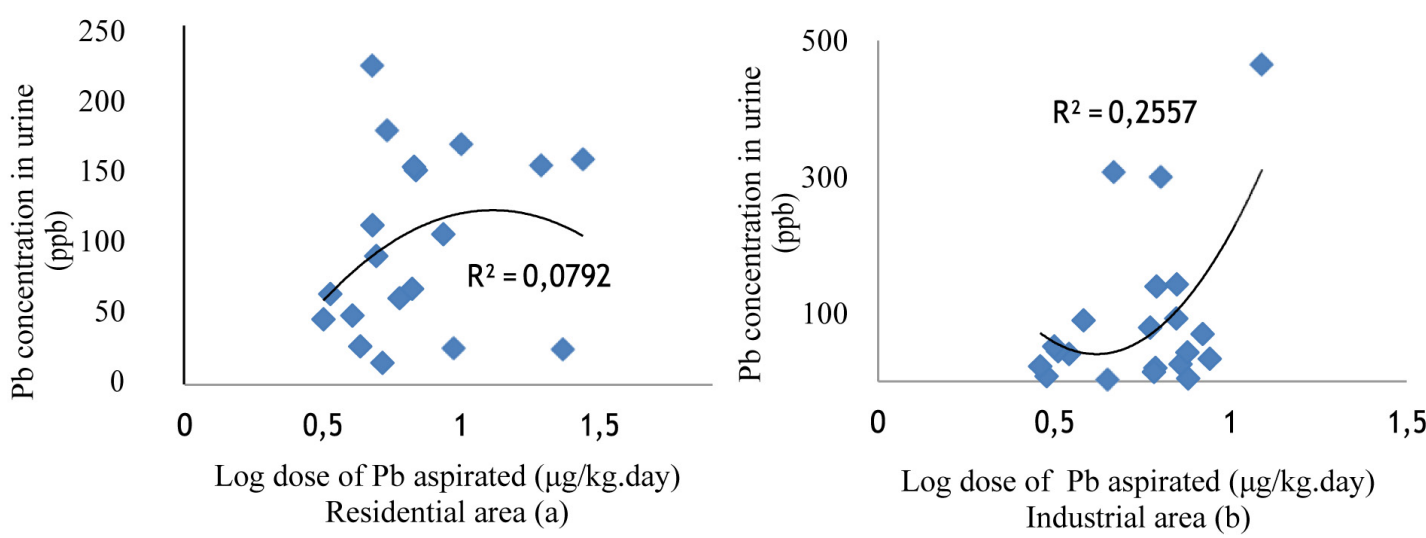

Figure 6. The relationship between urine lead concentration and lead dose

metabolic rate can be the cause of the seemingly no relationship between the lead concentration in urine and the aspirated lead concentration.

The lead kinetics in the human body can also be one of the causes that do not appear to be a meaningful relationship between the urine lead and the aspirated lead. The lead that enters the human body will then undergo displacement in the organs or tissues of the body, so not all aspirated lead will be expelled immediately in the form of lead in the urine (Rabinowitz 2016).

\section{CONCLUSION}

On the basis of the results obtained in this study, the average value of the lead concentration in the industrial area is higher than in the residential area, but still under the quality standard. In turn, the average $\mathrm{HI}$ value of the lead exposure to respiration in the two respondent areas shows a dangerous situation (HI> 1) where the average $\mathrm{HI}$ for the industrial and residential areas is 3.6 \pm 1.94 and $2.18 \pm 1,49$. With this result, traders and residents around the industrial area are exposed to a dangerous situation of lead exposure.

\section{Acknowledgements}

The authors would like to acknowledge the support of small team reaserch, environmental mangement technology reaserch group, Bandung Institut of Technology, and thank all those who have helped in completing this research.

\section{REFERENCES}

1. Abd El-Samad, M., Hanafi, H.A. 2017. Analysis of toxic heavy metals in cigarettes by Instrumental
Neutron Activation Analysis. Journal of Taibah University for Science, 11(5), 822-829.

2. Aceto, M., Abollino, O., Bruzzoniti, M.C., Mentasti, E., Sarzanini, C., Malandrino, M. 2002. Determination of metals in wine with atomic spectroscopy (flame-AAS, GF-AAS and ICP-AES); a review. Food Additives \& Contaminants, 19(2), 126-133.

3. ACGIH. 2004. American Conference of Governmental Industrial Hygienists, Threshold Limit Values for Chemical Substances and Physical Agents and Biological Exposure Indices, Cincinnati, Ohio.

4. Borges, A.R., Francois, L.L., Becker, E.M., Vale, M.G.R., Welz, B. 2015. Method development for the determination of chromium and thallium in fertilizer samples using graphite furnace atomic absorption spectrometry and direct solid sample analysis. Microchemical Journal, 119, 169-175.

5. Buser, M.C., Ingber, S.Z., Raines, N., Fowler, D. A., Scinicariello, F. 2016. Urinary and blood cadmium and lead and kidney function: NHANES 2007-2012. International journal of hygiene and environmental health, 219(3), 261-267.

6. Chagnes, A. and Swiatowska, J. (Eds.). 2015. Lithium process chemistry: Resources, extraction, batteries, and recycling. Elsevier.

7. Chen, H. Y., Li, A.J., Finlow, D.E. 2009. The lead and lead-acid battery industries during 2002 and 2007 in China. Journal of Power Sources, 191(1), 22-27.

8. de Freitas, C.U., De Capitani, E.M., Gouveia, N., Simonetti, M.H., De Silva, M.R.D.P., Kira, C.S. et al. 2007. Lead exposure in an urban community: investigation of risk factors and assessment of the impact of lead abatement measures. Environmental Research, 103(3), 338-344.

9. El Ati-Hellal, M., Hellal, F., Dachraoui, M., \& Hedhili, A. 2007. Plackett-Burman designs in the pretreatment of macroalgae for $\mathrm{Pb}, \mathrm{Cr}$ and $\mathrm{Al}$ determination by GF-AAS. Comptes Rendus Chimie, 10(9), 839-849.

10. Farahat, F.M., Fenske, R.A., Olson, J.R., Galvin, K., Bonner, M.R., Rohlman, D.S. et al. 2010. 
Chlorpyrifos exposures in Egyptian cotton field workers. Neurotoxicology, 31(3), 297-304.

11. Feng, Y., Huang, X., Sun, H., Liu, C., Zhang, B., Zhang, Z. et al. 2015. Framingham risk score modifies the effect of PM10 on heart rate variability. Science of the Total Environment, 523, 146-151.

12. Fink, A. 2015. How to conduct surveys: A step-bystep guide. Sage Publications.

13. Gottesfeld, P. and Pokhrel, A.K. 2011. Lead exposure in battery manufacturing and recycling in developing countries and among children in nearby communities. Journal of occupational and environmental hygiene, 8(9), 520-532.

14. Gratz, E., Sa, Q., Apelian, D., Wang, Y. 2014. A closed loop process for recycling spent lithium ion batteries. Journal of Power Sources, 262, 255-262.

15. Haefliger, P., Mathieu-Nolf, M., Lociciro, S., Ndiaye, C., Coly, M., Diouf, A. et al. 2009. Mass lead intoxication from informal used lead-acid battery recycling in Dakar, Senegal. Environmental Health Perspectives, 117(10), 1535-1540.

16. IC Consultants Ltd.: Lead: The Facts. London: IC Consultants Ltd., 2001. pp. 65-71.

17. International Lead and Zinc Study Group (ILZSG): "End Uses of Lead." [Online] Available at http:// www.ilzsg.org/static/enduses.aspx?from $=2$ (Accessed January 1, 2020)

18. Jaishankar, M., Tseten, T., Anbalagan, N., Mathew, B.B., Beeregowda, K.N. 2014. Toxicity, mechanism and health effects of some heavy metals. Interdisciplinary toxicology, 7(2), 60-72.

19. Kosnett, M.J., Wedeen, R.P., Rothenberg, S.J., Hipkins, K.L., Materna, B.L., Schwartz, B.S. et al. 2006. Recommendations for medical management of adult lead exposure. Environmental health perspectives, 115(3), 463-471.

20. Kurfürst, U. (Ed.). 2013. Solid sample analysis: direct and slurry sampling using GF-AAS and ETVICP. Springer Science \& Business Media.

21. Li, P., Lin, C., Cheng, H., Duan, X., Lei, K. 2015. Contamination and health risks of soil heavy metals around a lead/zinc smelter in southwestern China. Ecotoxicology and Environmental Safety, 113, 391-399.

22. Lisbona, D. and Snee, T. 2011. A review of hazards associated with primary lithium and lithium-ion batteries. Process Safety and Environmental Protection, 89(6), 434-442.

23. Mason, L.H., Harp, J.P., Han, D.Y. 2014. Pb neurotoxicity: neuropsychological effects of lead toxicity. BioMed research international, 2014.

24. Matović, V., Buha, A., Đukić-Ćosić, D., Bulat, Z. 2015. Insight into the oxidative stress induced by lead and/or cadmium in blood, liver and kidneys. Food and Chemical Toxicology, 78, 130-140.

25. Matta G. and Gjyli L. 2016. Mercury, lead and arsenic: impact on environment and human health. Journal of chemical and Pharmaceutical Sciences, 9(2), 718-725.

26. Monteith, J. and Unsworth, M. 2013. Principles of environmental physics: plants, animals, and the atmosphere. Academic Press.

27. NJ DOH. 2010. Lead Inorganic. New Jersey Department of Health.

28. OMEE 2010. Reference Dose for lead inorganic. Ontario Ministry of Environmental and Energy.

29. Parks, D.H., Tyson, G.W., Hugenholtz, P., Beiko, R. G. 2014. STAMP: statistical analysis of taxonomic and functional profiles. Bioinformatics, 30(21), 3123-3124.

30. Parzych, A. and Jonczak, J. 2014. Pine needles (Pinus sylvestris L.) as bioindicators in the assessment of urban environmental contamination with heavy metals. Journal of Ecological Engineering, 15(3).

31. Rabinowitz, M.B., Wetherill, G.W., Kopple, J.D. 1976. Kinetic analysis of lead metabolism in healthy humans. The Journal of Clinical Investigation, 58(2), 260-270.

32. Reyes, J.W. 2015. Lead exposure and behavior: effects on antisocial and risky behavior among children and adolescents. Economic Inquiry, 53(3), 1580-1605.

33. Sanders, T., Liu, Y., Buchner, V., Tchounwou, P.B. 2009. Neurotoxic effects and biomarkers of lead exposure: a review. Reviews on environmental health, 24(1), 15-46.

34. Santoso, M., Dwiana Lestiani, D., Hopke, P.K. 2013. Atmospheric black carbon in PM2. 5 in Indonesian cities. Journal of the Air \& Waste Management Association, 63(9), 1022-1025.

35. Savic, N., Racordon, D., Buchs, D., Gasic, B., Vernez, D. 2016. TREXMO: a translation tool to support the use of regulatory occupational exposure models. Annals of Occupational Hygiene, 60(8), 991-1008.

36. Taha, G., Box, G.P., Cohen, D.D., \& Stelcer, E. 2007. Black carbon measurement using laser integrating plate method. Aerosol Science and Technology, 41(3), 266-276.

37. Vinceti, M., Grill, P., Malagoli, C., Filippini, T., Storani, S., Malavolti, M., Michalke, B. 2015. Selenium speciation in human serum and its implications for epidemiologic research: a cross-sectional study. Journal of trace elements in medicine and biology, 31, 1-10.

38. Volchek, K., Thouin, G., Kuang, W., Li, K., Tezel, F.H., Brown, C.E. 2014. The release of lindane from contaminated building materials. Environmental Science and Pollution Research, 21(20), 11844-11855.

39. Waste, F.H. 2018. Hazardous waste management.

40. Zuberbier, T., Balke, M., Worm, M., Edenharter, G., Maurer, M. 2010. Epidemiology of urticaria: a representative cross-sectional population survey. Clinical and Experimental Dermatology: Clinical dermatology, 35(8), 869-873. 